정규논문 (Regular Paper)

방송공학회논문지 제 18 권 제4호, 2013년 7월 (JBE Vol. 18, No. 4, July 2013)

http://dx.doi.org/10.5909/JBE.2013.18.4.589

ISSN 2287-9137 (Online) ISSN 1226-7953 (Print)

$$
\begin{aligned}
& \text { 시각피로 모형: 카메라의 회전오차, 촬영 거리, 수렴 조건이 입체 } \\
& \text { 시각피로에 미치는 영향 } \\
& \text { 이 형 철 }{ }^{\mathrm{a})^{\ddagger}} \text {, 박 종 진 }{ }^{\mathrm{a})} \text {, 김 신 } \text { 우 }^{a}
\end{aligned}
$$

\title{
The Effects of Roll Misalignment Errors, Shooting Distance, and Vergence Condition of 3D Camera on 3D Visual Fatigue
}

\author{
Hyung-Chul O. $\left.\mathrm{Li}^{\mathrm{a}}\right)^{\ddagger}$, JongJin Park ${ }^{\mathrm{a})}$, and ShinWoo Kim ${ }^{\mathrm{a})}$
}

요 약

3 차원 영상이 유발하는 입체 시각 피로를 이해하기 위해서는 이미 제작된 콘텐츠가 유발하는 시각피로 뿐 아니라 영상이 생성되는 촬 영 시점에 영상을 결정하는 카메라 파라미터가 시각피로에 미치는 영향에 대한 연구가 필요하다. 본 연구는 카메라 파라미터인 회전 오 차, 촬영 거리, 수렴 조건이 입체 시각 피로에 미치는 영향을 검증하고 모형화 하였다. 연구 결과 회전 오차, 촬영 거리, 수렴 조건이 모 두 입체 시각 피로에 영향을 미치며 특히 카메라 오정렬 관련 파라미터인 회전 오차는 상대적으로 낮은 화면 시차에서 입체 시각 피로 에 큰 영향을 미치는 것을 확인할 수 있었다.

\begin{abstract}
In order to understand 3D visual fatigue, it is necessary to examine the visual fatigue induced by camera parameters as well as that induced by a pre-existing 3D content. In the present study, we examined the effects of camera parameters, such as roll misalignment error, shooting distance and vergence condition on 3D visual fatigue and we modelled it. The results indicate that roll misalignment error, shooting distance and vergence condition affect 3D visual fatigue and the effect of roll misalignment error on $3 \mathrm{D}$ visual fatigue is evident specifically when screen disparity is relatively small.
\end{abstract}

Keyword : Roll misalignment error, Camera parameter, 3D visual fatigue, modelling

\footnotetext{
a) 광운대학교 산업심리학과 (Department of I/O Psychology, Kwangwoon University)

₹ Corresponding Author : 이형철(Hyung-Chul O. Li)

E-mail: hyung@kw.ac.kr

Tel: $+82-2-940-5425$

※ 본 연구는 산업통상자원부 및 한국산업기술평가관리원의 산업원천기술개발사업 $[10038745$, 인체안전성을 위한 $3 \mathrm{D}$ 기기/장비 중심의 휴먼팩터 연구]와 2012년 광운대학교 연구년 사업(이형철)의 일환으로 수행하였음.

Manuscript received February 13, 2013 Revised April 24, 2013 Accepted June 5, 2013
} 


\section{I. 서 론}

양안시차를 이용하여 3 차원 깊이를 지각하는 인간 시각 시스템에 생생한 3 차원 깊이 정보를 제공하기 위하여 다양 한 $3 \mathrm{D}$ 촬영 장비와 $3 \mathrm{D}$ 디스플레이가 개발되었다. 시청자에 게 $3 \mathrm{D}$ 정보인 양안시차만 제공하면 특별한 문제없이 시청자 로 하여금 $3 \mathrm{D}$ 를 즐길 수 있게 하리란 기대와 달리 시청자는 $3 \mathrm{D}$ 콘텐츠를 즐기는데 한계가 있다. 인간의 3D 시각시스템 은 $3 \mathrm{D}$ 콘텐츠를 즐기기 위한 목적으로 진화된 것이 아니며 자연의 $3 \mathrm{D}$ 환경에 존재하는 3 차원 공간의 특성을 파악하고 이에 적절히 대응하기 위하여 오랜 세월 진화된 것이담] 따라서 자연의 $3 \mathrm{D}$ 환경에서 깊이를 지각하고 이에 대응하는 데 인간의 $3 \mathrm{D}$ 시각시스템은 특별한 문제가 없다. 하지만 $3 \mathrm{D}$ 디스플레이에 제시되는 $3 \mathrm{D}$ 콘텐츠를 시청할 때에 시청자는 자주 시각적 피로를 경험한다. $3 \mathrm{D}$ 산업의 발전을 지속적으 로 이루어 가기 위해서는 $3 \mathrm{D}$ 디스플레이 및 촬영 하드웨어 제작 기술과 $3 \mathrm{D}$ 콘텐츠 제작 기술의 발전과 함께 인간 시청 자가 경험하는 시각피로의 문제가 해결되어야 한다.

$3 \mathrm{D}$ 디스플레이에 제시되는 콘텐츠를 시청할 때 발생하는 시각피로의 직접적인 원인은 시청자의 안구에서 발생하는 수렴과 조절의 불일치 때문인 것으로 알려져 있다 ${ }^{[2]}$. 양안에 제시되는 영상으로부터 단일 상을 형성하고 ${ }^{[3]}$ 깊이감을 형 성하기 위해 두 눈은 시차에 따라 $3 \mathrm{D}$ 디스플레이의 앞 또는 뒤에 수렴 (vergence)을 형성하게 되는데, 이 때 조절은 화면 까지의 거리에 의해 결정된다 ${ }^{[3][4]}$. 양안에 입력되는 시차가 0 이 아닌 이상 수렴점은 디스플레이와 다른 곳에 형성되는 데 이 때문에 수렴거리와 조절거리가 일치하지 않게 되고 이것이 수렴-조절 불일치를 형성한다. 수렴-조절 불일치는 인위적으로 $3 \mathrm{D}$ 정보인 양안시차를 전달하고자 하는 현재의 $3 \mathrm{D}$ 디스플레이 기술의 한계이다. 시각피로를 유발하는 디스 플레이 요인은 이외에도 왼 쪽 눈에 입력되는 영상이 오른 쪽에도 일부 입력되어 발생하는 크로스톡 요인이 있다 ${ }^{[5]}$. 디 스플레이 요인 이외에 콘텐츠 요인, 시청자 요인 그리고 시 청환경요인 등이 시각피로 유발요인으로 지목되고 있담[]. 시각피로를 유발하는 디스플레이 요인과 시청환경 요인 그리고 시청자 요인 등은 일부 연구가 진행되었으나나닥 콘 텐츠 제작 시에 관여하는 $3 \mathrm{D}$ 카메라로 인한 시각피로에 대 한 연구는 드물다. $3 \mathrm{D}$ 영상장비가 보급되지 않는 경우에
사용할 수 있는 방법은 두 대의 영상장비를 리그에 설치하 고 동기화하여 $3 \mathrm{D}$ 입체영상을 획득하는 것인데, 이 때 리그 에 두 대의 영상장비를 설치할 때 두 대 영상장비의 광축정 열을 제대로 하는 것이 매우 중요하다. 예를 들어, 한 대의 영상장비가 다른 쪽 영상장비에 비하여 시축을 중심으로 상대적으로 회전이 되어 있다면 촬영되는 영상은 그 만큼 좌우 영상 간에 회전오차가 발생할 수밖에 없다. 또한 하나 의 영상장비가 다른 쪽 영상장비에 비해 수직축에서 상대 적으로 어긋나 있다면 좌우 영상 간에 수직오차가 발생한 다. 광축 오정렬이 유발하는 오차는 수학적으로 계산이 가 능하며 이에 대한 수리적 계산방식이 존재한다 ${ }^{[8]}$. 회전오차 와 수직오차가 시각 피로에 영향을 미칠 수 있다는 것은 이미 알려져 있으나미 각 오차가 시각 피로에 미치는 영향 과 $3 \mathrm{D}$ 입체 자극에 의하여 유발되는 일반적인 입체 자극이 어떤 관계를 가지는지 아직 측정되지 않았다.

카메라의 광축 오정렬로 인한 시각피로의 문제는 $3 \mathrm{D}$ 콘 텐츠 제작시에 고려되어야할 문제일 뿐만 아니라 3D 영상장 비 생산 단계에서도 중요하게 고려되어야 할 문제이다. 최 근, 다양한 $3 \mathrm{D}$ 카메라와 $3 \mathrm{D}$ 캠코더가 출시되고 있는데, 산 업체에서 $3 \mathrm{D}$ 영상장비를 생산할 때 영상장비 광축 오정렬을 최소화 하는 것이 시각피로를 최소화하는 중요한 방법이기 에 광축 오정렬을 최소화하고자 최선을 다한다. 문제는 생산 단계에서 광축 오정렬은 발생할 수 밖에 없으며 중요한 것은 얼마나 정밀하게 최소화하느냐 하는 것인데, 광축 오정렬을 최소화하는데 비용이 발생한다. $3 \mathrm{D}$ 영상장비 생산자 입장에 서는 광축 오정렬을 최소화하는 것이 바람직하겠지만 생산 단가를 절약하기 위해 인간 사용자의 시각피로에 영향을 미 치지 않는 한도에서는 생산단계에서의 미세한 오정렬을 허 용할 수 있을 것이다. 여기서 고려해야 할 것은 $3 \mathrm{D}$ 영상장비 의 광축 오정렬을 어느 정도까지 허용할 것이냐는 점이다.

본 연구의 목적은 광축 오정렬 중에서 특히 왼 쪽과 오른 쪽 영상 장비의 회전축에서의 상대적 차이로 인한 회전오 차가 시각피로에 미치는 영향을 시청자를 대상으로 정량화 하고 이를 기반으로 회전오차가 시각피로에 미치는 영향을 모형화하는 것이다. 시각피로의 모형을 구축하게 되면 실 험에서 검증하지 않은 다양한 조건에서의 시각피로를 효과 적으로 예측하는 것이 가능하다. 또한, $3 \mathrm{D}$ 콘텐츠 제작 시 에 영상장비의 회전오차를 어느 정도까지 허용할 것인지 
그리고 $3 \mathrm{D}$ 영상 장비 생산 시에 좌 우 영상 장비의 회전오 차를 어느 정도까지 허용할 것인지에 대한 규준을 마련하 는 것이 가능하다.

이런 목적을 온전히 달성하려면 오직 회전오차만 측정하 는 것으로는 부족하다. 앞서 언급한 바와 같이 입체 시각 피 로의 원인은 양안 시차에 의한 수렴-조절 불일치이며 이는 결국 화면 시차에 의하여 유발된다마. 또한 회전 오차가 미치 는 영향은 카메라 회전에 의한 양안 영상의 수평 및 수직 시 차에 의하여 유발된다. 따라서 회전 오차가 입체 시각 피로에 미치는 영향을 정확하게 확인하려면 회전오차 뿐 아니라 입 체 지각을 위한 화면 시차 역시 반드시 포함하여야 한다.

시청자의 시각피로에 영향을 미치는 요인이 디스플레이 요인, 콘텐츠 요인, 시청자 요인 그리고 시청환경 요인과 같이 다양하고 이들의 상호작용이 복잡하기 때문에 모든 가능한 요인을 고려하여 실험 상황을 구성하는 것은 가능 하지 않다. 본 연구에서는 연구의 목적을 온전히 달성하기 위하여 카메라의 회전오차 요인 이외에 3D 카메라 작동에 직접적인 영향을 미치는 촬영거리 그리고 양 카메라의 수 렴거리(또는 주시각 거리)를 조작하여 촬영거리와 카메라 수렴거리가 카메라의 회전오차와 함께 시각피로에 미치는 영향을 검증하도록 실험을 설계하였다. 회전오차와 촬영거 리 그리고 카메라의 수렴거리를 조작하여 실험자극을 구성 하고 본 연구실에서 구성한 시각피로 측정방법을 활용하여 시청자를 대상으로 시각피로를 측정하였다 ${ }^{[6]}$. 회전오차와 촬영거리 그리고 카메라 수렴거리가 시각피로에 영향을 미 치는 정도를 검증하기 위하여 변량분석을 이용하여 각 요 인의 효과와 함께 상호작용 정도를 검증하였으며 실험에서 검증하지 않은 조건에서의 시각피로를 예측하기 위하여 실 험에서 획득된 데이터를 설명할 수 있는 시각피로 모형을 구축하고 그 통계적 유의성을 검증하였다.

\section{II. 실험}

\section{1. 참가자 및 장치}

광운대학교 학부생 및 대학원생 31 명이 참가하였다. 이 중 26 명 $(83.9 \%)$ 의 참가자는 연구의 목적을 알지 못하는 참
가자였다. 모든 참가자는 정상 시력 또는 교정된 정상 시력 을 가지고 있었다.

$3 \mathrm{D}$ 자극을 제시하기 위하여 $1920 \times 1080$ 의 해상도와 $60 \mathrm{~Hz}$ 의 화면 갱신률을 지원하는 현대 $\mathrm{IT}$ 주식회사의 $3 \mathrm{D}$ 디스플레이 S465D (화면 너비 $101.8 \mathrm{~cm}$, 화면 높이 57.3 $\mathrm{cm}$ )를 사용하였다. 이 장비는 편광 방식 (GPR, Glass Patten Retarded type)으로 양 눈에 서로 다른 영상을 제시 하기 위하여 광학적 처리가 된 안경을 사용한다. 편광 안경 을 사용하면 1080 개의 세로 열 중 짝수 열 (540개)에 나타나 는 영상은 왼쪽 눈에 제시되며, 홀수 열 (540개)에 나타나는 영상은 오른쪽 눈에 제시된다. 따라서 제시한 영상 자극의 수직 해상도는 실제 영상의 해상도에 비하여 절반으로 감소 하게 되어 실험에서 사용한 $3 \mathrm{D}$ 영상의 실질적인 해상도는 $1920 x 540$ 이었다. 온전한 해상도의 영상은 디스플레이의 $3 \mathrm{D}$ 모드 변환 과정에서 디스플레이 고유의 방식으로 양안 영상을 분할하며 이 과정에서 안티 앨리어싱(Anti-aliasing) 과 같은 영상 왜곡이 나타날 수 있다. 이런 영상 왜곡의 효과 는 모든 실험 조건에서 동일하게 적용되기 때문에 조건 사이 의 차이에 체계적인 영향을 미칠 가능성은 거의 없으나 전체 적으로 시각 피로에 영향을 미칠 가능성도 존재한다.

입체 시각 피로는 주관적 방법인 설문법을 통하여 측정되 었다. 입체 시각 피로를 측정하는데 사용된 측정 도구는 Likert 7점 척도를 사용한 16개의 문항 (신뢰도 측정을 위한 역문항 5 문항 포함)으로 입체 시각 피로를 측정하도록 제작 된 도구이다. 이 도구는 입체 시각 피로를 세 가지 요인 (안 구 통증, 울렁거림, 상흐림)으로 측정하도록 구성되었으며, 특히 짧은 시간동안 제시되는 $3 \mathrm{D}$ 자극의 시각 피로를 측정 하기 위하여 개발된 도구이다. 이 도구는 Likert 7점 척도를 사용하며, 따라서 점수 구간을 크게 셋으로 나눌 수 있다. 즉 1 3점의 응답은 해당하는 자극이 불편하지 않음을 의미 하며, 4점은 그저 그렇다, 그리고 5 7점의 응답에 해당하는 자극은 자극이 불편하거나 피로하다는 의미의 응답이다.

자극이 제시되는 시간과 위치를 정확하게 통제하기 위하 여 Mathwork사의 Matlab과 심리학 실험용 함수 모음인 Psychophysics toolbox $3^{[10]-[12]}$ 를 사용하였다. 이 도구를 사용하여 모니터의 화면 갱신률과 해상도에 맞춰 자극을 정확하게 제시하였다. 


\section{2. 자극 구성}

본 연구의 목적은 카메라 파라미터 (회전 오차, 촬영 거 리, 수렴 조건)의 변화가 입체 시각 피로에 미치는 영향을 확인하고, 그 결과를 기술하는 함수를 개발하는 것이다. 이 런 연구 목적을 달성하려면 카메라 파라미터가 입체 시각 피로에 미치는 영향을 확인하여야 한다. 즉 연구자가 관심 가지는 변인을 제외한 모든 요인을 통제한 상태로 자극을 촬영한 다음 그 자극이 참가자에게 유발시키는 입체 시각 피로를 측정하여야 한다. 그러나 $3 \mathrm{D}$ 입체 자극을 실제 카메 라로 촬영하는 것은 많은 문제를 유발할 가능성이 있다. 특 히 문제가 되는 부분은 잠재적으로 피로에 영향을 미칠 가 능성이 있는 다양한 변인을 전부 통제하는 것이 매우 어렵 거나 또는 불가능하다는 점이다. 본 연구에서는 이런 한계 를 극복하기 위하여 실험 자극의 촬영 상황을 가정하고 그 상황에서 나타나는 다양한 촬영 파라미터를 구성한 다음 실제 촬영 시 자극이 어떻게 나타나는지 시뮬레이션 하는 방법을 사용하였다.

시뮬레이션은 Woods와 동료들의 연구 ${ }^{[8]}$ 를 바탕으로 이 루어졌다. 이 연구는 두 대의 카메라를 사용하여 $3 \mathrm{D}$ 촬영을 했을 때 외부 세계의 한 점 $\mathrm{x}, \mathrm{y}, \mathrm{z}$ 가 특정한 크기의 $3 \mathrm{D}$ 디스 플레이의 좌측 및 우측 영상의 좌표 공간 $\mathrm{x}, \mathrm{y}$ 에 각각 어떻 게 투사되는지 기하학적 방법을 사용하여 분석하였다. 이 연구에 따르면 우리는 카메라를 통하여 획득한 영상이 $\mathrm{ccd}$ 에 어떻게 기록되는지, 그리고 $\mathrm{ccd}$ 에 기록된 영상이 어떻게 $3 \mathrm{D}$ 디스플레이 화면에 투사되는지 직접 계산할 수 있다. Woods 등의 방법을 사용하면 카메라로 실제 영상을 촬영 할 때 나타날 수 있는 다양한 광학적 문제를 회피하면서 동시에 가능한 한 실제 촬영 영상과 동일한 자극을 얻는 것이 가능하다. 또한 시뮬레이션 방법을 사용하면 연구에 서 조작하지 않은 모든 변인을 쉽게 통제할 수 있어 연구 목적에 정확하게 부합하는 자극을 구성할 수 있다. 시뮬 레이션에 사용하기 위하여 Sony사의 HDR-TD10의 스펙 중 일부를 사용하였다. 사용한 스펙은 초점 거리 (Focal length: $3.4 \mathrm{~cm})$ 와 ccd 크기 $(1 / 4 "$, width: $3.2 \mathrm{~cm})$ 였다. 자극은 무선적인 위치에 정사각형 점 (변의 길이: $1 \mathrm{~cm}$ ) 을 포함하고 있는 정사각형 (변의 길이: $25 \mathrm{~cm}$ )으로, 실험
조건에 따라 다양한 파라미터를 가진 카메라로 대상을 화 면 정 중앙에 위치시킨 상태에서 촬영하는 것을 가정하여 구성하였다 (그림 1). 독립변인으로 사용한 파라미터는 회 전 오차, 촬영 거리, 수렴 조건이었다. 회전 오차는 오차가

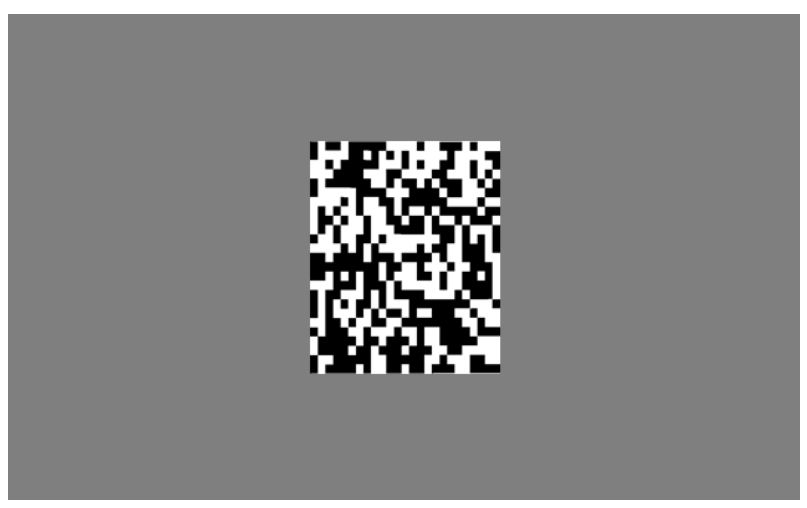

그림 1. 도식적인 자극 화면 예시

Fig. 1. An example of schematic stimulus presentation

a.
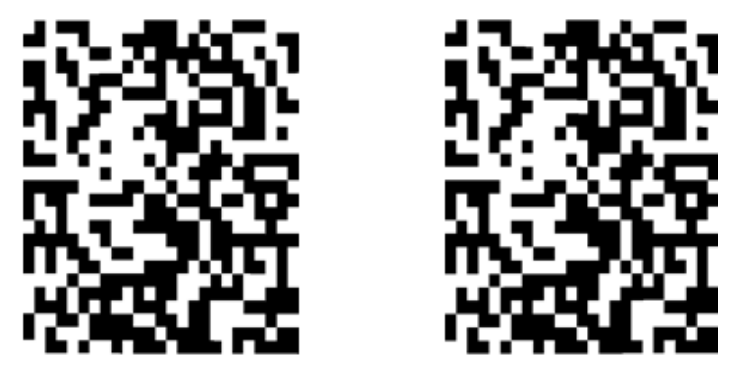

b.
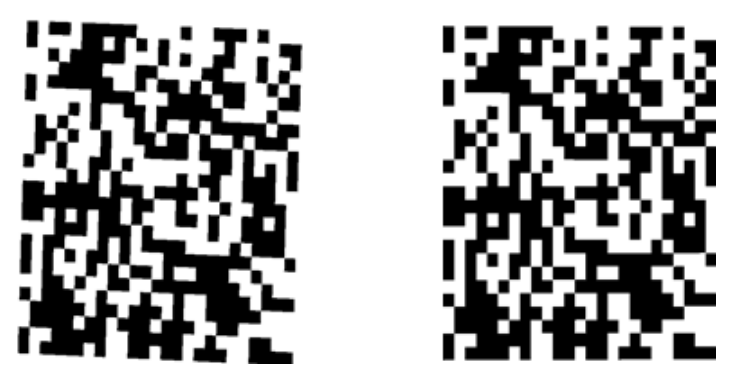

그림 2. 회전 오차 예시. a. 회전 오차가 없는 자극 $\left(0^{\circ}\right)$.b. 최대 회전 오차를 가진 자극 $\left(2^{\circ}\right)$

Fig. 2. Examples of roll misalignment error. a. A stimulus with no roll misalignment error $\left(0^{\circ}\right)$. b. A stimulus with maximum roll misalignment error $\left(2^{\circ}\right)$ 
없는 $0^{\circ}$ 조건부터 $0.5^{\circ}$ 씩 오차가 증가하여 총 5 조건 $\left(0^{\circ}\right.$, $0.5^{\circ}, 0.1^{\circ}, 1.5^{\circ}, 2^{\circ}$ ) 으로 구성되었다 (그림 2). 이 조건에 따라 오른쪽 카메라의 영상이 우측 방향으로 회전하게 된 다. 촬영 거리는 $1 \mathrm{~m}, 2 \mathrm{~m}, 4 \mathrm{~m}$ 로 총 3 조건을 사용하였다. 수렴 조건은 양안 시차의 방향성과 크기를 고려하여 교차 시차 (촬영 거리가 수렴 거리에 비하여 $40 \%$ 가 되도록 구성, 화면시차 큼), 시차 없음 $(100 \%$, 수렴 거리와 촬영 거리가 동일), 비교차 시차 (촬영 거리가 수렴 거리의 $140 \%$ 가 되도 록 구성, 화면시차 작음) 세 조건으로 구성하였다 (표 1). 회전 오차는 수평 및 수직 시차를 생성하며 수렴 조건과 촬영 거리는 결합하여 수평 화면 시차를 생성한다 (표 2). 이렇게 구성한 자극을 중립적인 회색 $(127 / 127 / 127, \mathrm{RGB})$ 배경과 함께 제시되었다.

표 1. 촬영 거리에 따른 실제 수렴 거리

Table 1. Actual vergence distance at each shooting distance

\begin{tabular}{|c|c|c|}
\hline $\begin{array}{c}\text { Vergence } \\
\text { condition }\end{array}$ & $\begin{array}{c}\text { Shooting distance } \\
(\mathrm{m})\end{array}$ & $\begin{array}{c}\text { Vergence distance } \\
(\mathrm{m})\end{array}$ \\
\hline \multirow{3}{*}{ Crossed disparity } & 1 & 2.5 \\
\cline { 2 - 3 } & 2 & 5 \\
\cline { 2 - 3 } & 4 & 10 \\
\hline \multirow{3}{*}{ No disparity } & 1 & 1 \\
\cline { 2 - 3 } & 2 & 2 \\
\cline { 2 - 3 } & 4 & 4 \\
\hline \multirow{3}{*}{$\begin{array}{c}\text { Uncrossed } \\
\text { disparity }\end{array}$} & 1 & 0.71 \\
\cline { 2 - 3 } & 2 & 1.43 \\
\cline { 2 - 3 } & 4 & 2.86 \\
\hline
\end{tabular}

표 2. 촬영 거리와 수렴 조건에 의하여 생성된 화면 시차

Table 2. Screen disparities generated by combinate of shooting distance and vergence condition

\begin{tabular}{|c|c|c|c|}
\hline \multirow{2}{*}{$\begin{array}{c}\text { Shooting } \\
\text { distance } \\
(\mathrm{m})\end{array}$} & \multicolumn{3}{|c|}{ Vergence condition } \\
\cline { 2 - 4 } & $\begin{array}{c}\text { Crossed } \\
\text { disparity }\end{array}$ & No disparity & $\begin{array}{c}\text { Uncrossed } \\
\text { disparity }\end{array}$ \\
\hline 1 & $1^{\circ} 50^{\prime} 15^{\prime \prime}$ & $0^{\circ} 2^{\prime} 53^{\prime \prime}$ & $1^{\circ} 18^{\prime} 9^{\prime \prime}$ \\
\hline 2 & $0^{\circ} 55^{\prime} 36^{\prime \prime}$ & $0^{\circ} 0^{\prime} 21^{\prime \prime}$ & $0^{\circ} 37^{\prime} 39^{\prime \prime}$ \\
\hline 4 & $0^{\circ} 27^{\prime} 52^{\prime \prime}$ & $0^{\circ} 0^{\prime} 2^{\prime \prime}$ & $0^{\circ} 18^{\prime} 39^{\prime \prime}$ \\
\hline
\end{tabular}

실험 자극은 촬영 조건에 의하여 생성되었기 때문에 실 험 결과를 확실히 입체 시각 피로에 의한 결과로 통제하려
면 자극이 적절한 양안 시차를 유발하도록 제작되었는지 확인할 필요가 있다. Shibata와 동료들의 연구 ${ }^{[5]}$ 에 따르면 본 연구에서 사용한 관찰 거리 0.5 Diopter $(2 \mathrm{~m})$ 의 수렴 거리를 가지는 경우 초점 거리가 약 1.5 Diopter 내에 존재 하여야 단일 상을 지각할 수 있다. 본 연구에서 사용된 자극 의 양안 시차를 모두 확인한 결과 가장 높은 양안 시차를 가지는 회전 오차 $2^{\circ}$, 촬영 거리 $1 \mathrm{~m}$, 교차 시차 자극의 화 면 시차는 약 $1^{\circ} 58^{\prime}$ 이다. 최대 양안 시차를 가진 자극은 양 안 거리 $6 \mathrm{~cm}$ 인 관찰자에게 1.07 Diopter 거리에 있는 자극 이 가지는 양안 시차로 제시된다. 따라서 최대 양안 시차를 가지는 실험 자극의 초점 거리도 단일 상을 지각할 수 있는 범위 내에 있음을 확인할 수 있다.

한편 실험 조건에서 수렴 거리와 촬영 거리를 조작하는 것은 화면 시차 뿐 아니라 키스톤 왜곡 (keystone distortion)을 유발한다. 이 효과는 영상을 후처리하는 것으로 통제할 수 있으나, 본 연구에서는 수렴 및 촬영 거리에서 유발하는 시각 피로의 일부로 간주하여 그 효과를 통제하 지 않았다.

\section{3. 실험 설계 및 실험 절차}

본 연구의 목적은 카메라 파라미터 변화에 따라서 주관 적 입체 시각 피로가 어떻게 변화하는지 밝혀내고 그 결과 를 모형화 하는 것이다. 이런 목적을 달성하기 위하여 세 가지 카메라 파라미터 (회전 오차, 촬영 조건, 수렴 조건)를 변화시키고 그에 따른 입체 시각 피로 변화를 측정하기 위 한 실험을 구성하였다. 모든 독립변인 조건 (회전 오차: 5 조 건, 촬영 조건: 3 건, 수렴 조건: 3 건)은 전부 교차하였고, 그 결과 총 45 개의 조건이 구성되었다. 모든 조건이 반복 측 정되었으며 한 참가자가 45 개의 조건을 한 번씩 반복하였 다.

참가자가 실험실에 도착하면 실험 내용이 시각적 피로를 유발할 수 있으며 언제든지 실험을 멈출 수 있다는 내용을 포함하여 실험 전반에 대하여 안내받았다. 참가자는 디스 플레이로부터 $2 \mathrm{~m}$ 거리에 앉아서 무선적으로 제시되는 45 개의 자극을 하나씩 관찰하고, 자극이 사라진 다음 방금 자 극을 관찰하면서 느껴진 피로감에 대한 설문에 응답하도록 
요청받았다. 자극은 10 초간 제시되었다. 참가자는 자극이 사라지고 나면 시간제한 없이 설문에 응답하도록 요청받았 으며, 응답이 완료된 것을 확인하면 참가자에게 다음 자극 제시를 위하여 화면을 주시할 것을 요청하고 다음 자극을 제시하였다. 이 과정은 모든 자극에 대하여 동일하게 반복 하여 총 45 회 측정이 완료되면 실험을 종료하였다.

\section{4. 결과 및 논의}

결과 분석에 앞서 각 참가자의 설문 내용을 검토해 본 결과 한 명의 참가자가 모든 문항에 대하여 전부 같은 번호 로 응답하였다. 이 참가자의 경우 측정 결과의 신뢰성을 보 장할 수 없어 분석에서 제거하기로 결정하였다. 따라서 해 당하는 참가자의 자료를 제외한 30 명의 자료를 분석에 사
용하였다.

회전 오차 $\left(0^{\circ}, 0.5^{\circ}, 0.1^{\circ}, 1.5^{\circ}, 2^{\circ}\right)$, 촬영 조건 $(1 \mathrm{~m}, 2$ $\mathrm{m}, 4 \mathrm{~m}$ ), 수렴 조건 (촬영 거리 대기 $40 \%, 100 \%, 140 \%$ )이 참가자의 입체 시각 피로에 미치는 영향을 확인하기 위하 여 반복측정 분산 분석을 사용하여 독립변인에 따른 피로 도 차이를 검증하였다.

그림 3에서 볼 수 있는 것처럼 모든 주효과 변인은 그 크기가 증가함에 따라 더 높은 입체 시각 피로와 관련된 것을 확인할 수 있었다. 또한 이런 차이는 모든 주효과 변인 에서 통계적으로 유의미하게 나타났다 (회전 오차: $\mathrm{F}(4$, $112)=32.4, \mathrm{p}<.001$, 촬영 거리: $\mathrm{F}(2,56)=29.5, \mathrm{p}<.001$, 수렴 조건: $\mathrm{F}(2,56)=25.8, \mathrm{p}<.001)$. 앞서 언급한 바와 같이 시각 피로 측정 도구가 Likert 7점 척도로 구성되어 있기 때문에 참가자의 응답이 1 3점 범위 내에 있는 경우에만
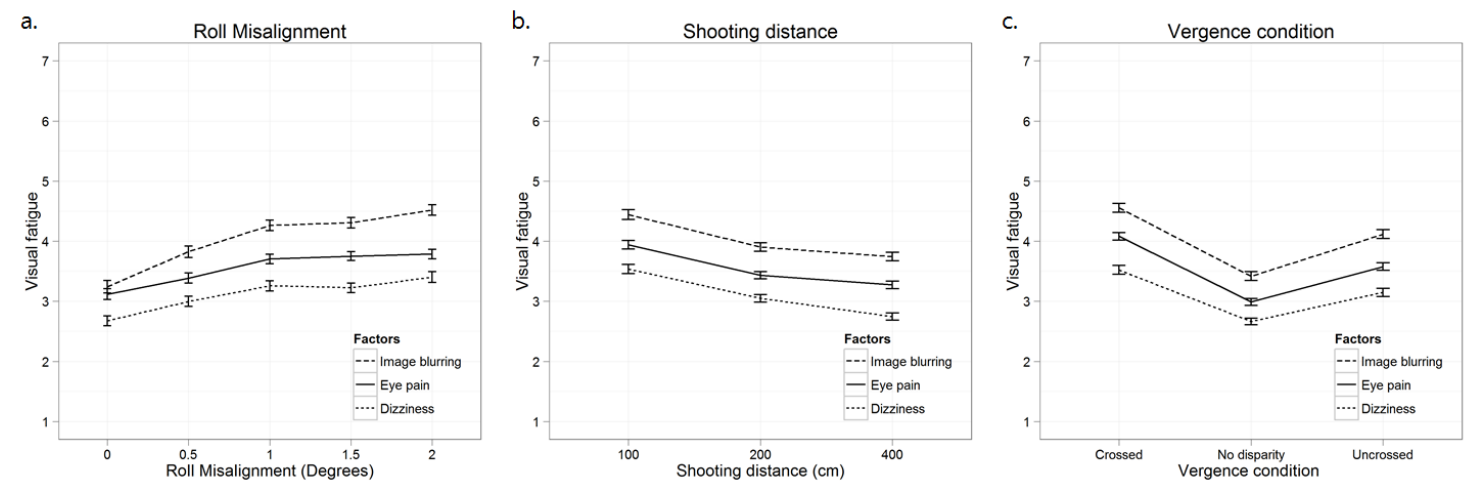

그림 3. 회전 오차, 촬영 거리, 수렴 조건의 주효과

Fig. 3. Main effect of roll misalignment error, shooting distance and vergence condition.
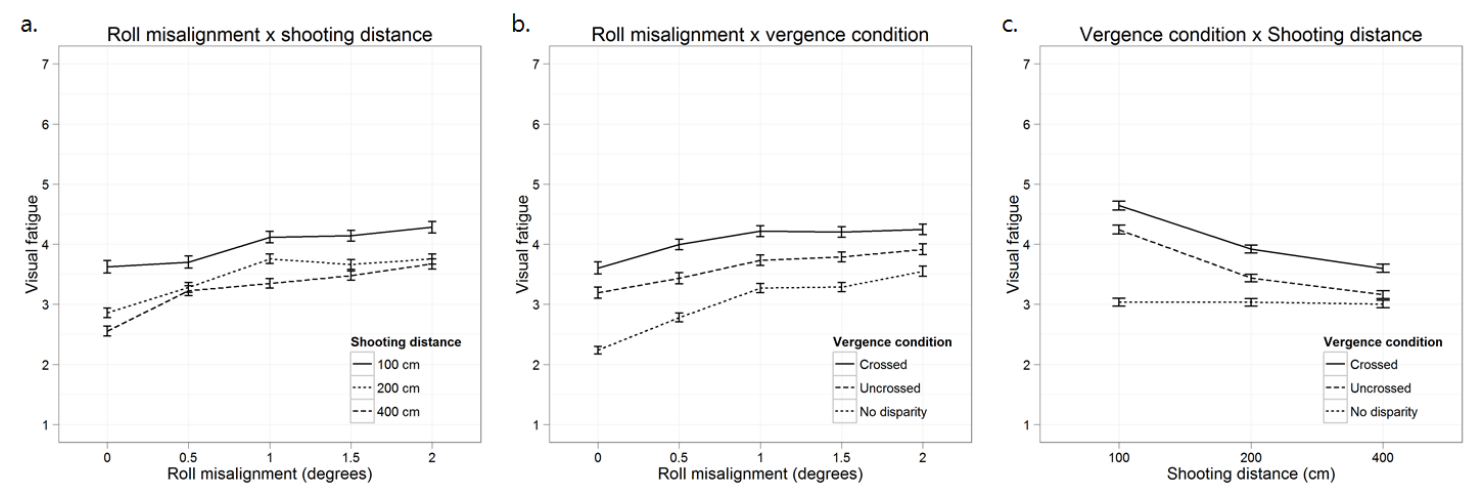

그림 4. 회전 오차, 촬영 거리, 수렴 조건의 2원 상호작용 결과 그래프

Fig. 4. 2 way interaction of roll misalignment error, shooting distance and vergence condition. 
불편하지 않다고 응답한 것으로 간주할 수 있다. 이 기준에 따르면 회전 오차는 0 도 (그림 3a), 촬영 거리는 $4 \mathrm{~m}$ (그림 $3 b)$, 수렴 조건은 시차가 없는 경우 (그림 3c)가 입체 시각 피로가 가장 낮아지는 안전선이라고 말할 수 있다.

그림 4에 2원 상호작용 효과 분석 결과를 제시하였다. 2 원 상호작용 효과 역시 모든 조건에서 통계적으로 유의미 한 차이를 보였다 (회전 오차 $\times$ 수렴 조건: $\mathrm{F}(8,224)=3.1$, $\mathrm{p}<0.01$, 회전 오차 $\times$ 촬영 거리: $\mathrm{F}(8,224)=2.5, \mathrm{p}<$ 0.001 , 수렴 조건 $\times$ 촬영 거리: $\mathrm{F}(8,224)=12.3, \mathrm{p}<0.001)$. 이 분석을 통하여 카메라 파라미터가 입체 시각 피로에 미 치는 영향을 두 가지 측면에서 설명할 수 있다.

첫째, 그림 $4 \mathrm{a}$ 와 $4 \mathrm{~b}$ 에서 볼 수 있는 것처럼 회전 오차는 단독으로 입체 시각 피로에 영향을 미치며, 그 효과는 수렴 조건 및 촬영 거리에 의한 수평 화면 시차가 적을 때 더 커지는 경향을 보이는 것을 확인할 수 있다. 이는 회전 오차 에 의하여 생성된 수직 및 수평 화면 시차의 효과가 고유한 입체 시각 피로 유발 인자로서 영향을 미치지만 그 효과가 수렴 조건 및 촬영 거리에 의하여 생성된 수평 화면 시차에 완전히 독립적이지 않다는 것을 시사한다.

둘째, 그림 $4 \mathrm{c}$ 에서 확인할 수 있는 것처럼 촬영 거리에 따른 입체 시각 피로의 차이는 시차 조건에 따라 영향 받는 경향을 보인다. 즉 화면 시차가 없는 경우에는 입체 시각 피로가 나타나지 않으나 화면 시차가 증가함에 따라서 입 체 시각 피로가 증가하는 경향을 보인다. 시차가 존재하는 두 조건 ( $40 \%$ 및 $140 \%$ 조건)에서는 입체 시각 피로가 상당 히 증가하여 촬영 거리가 $1 \mathrm{~m}$ 인 경우 참가자들이 입체 시 각 피로가 없거나 (1 3점) 애매하다고 (4점) 응답한 기준 이상으로 증가하여 참가자들이 확실하게 피로감을 느꼈다 고 보고한 것을 확인할 수 있었다. 이는 화면 시차가 존재하 는 경우에만 입체 시각 피로가 증가한다는 의미로 해석할 수 있으며 입체 피로 측정 도구가 실제 입체 피로를 정확하 게 반영한다는 것을 시사한다.

\section{5. 피로도 예측 함수 개발}

앞서 언급한 바와 같이 본 연구는 크게 두 가지 목적을 수행하기 위하여 수행되었다. 첫째, 카메라 파라미터의 변
화에 따라 참가자의 피로 및 불편감이 어떻게 변화하는지 측정하는 것이다. 이런 목적은 앞서 기술한 바와 같이 실험 적 절차를 통하여 수행되었다. 둘째, 각 변인에 의하여 유발 된 피로 및 불편감을 예측하기 위한 수식을 개발하는 것이 다. 이는 실험적 절차를 통하여 수집된 자료를 바탕으로 피 로 예측 모형을 구성하고 그 모형이 얼마나 실험적 결과를 잘 기술하는지 통계적인 방법을 바탕으로 검증하는 것으로 수행될 수 있다.

따라서 두 번째 목표인 카메라 파라미터 변화에 따른 피로 도 예측 함수를 개발하기 위하여 독립 변인인 회전 오차, 촬영 거리, 수렴 조건에 따라 종속 변인인 입체 시각 피로가 변화하 는 양상을 설명하기 위한 회귀 분석을 수행하였다. 그러나 앞 선 실험 결과 분석에서 나타난 바와 같이, 촬영 거리 변인은 수렴 조건 변인에 의하여 그 효과가 드러난다. 즉, 양안 시차 가 없는 $100 \%$ 조건에서 시각 피로는 변화하지 않으나, 양안 시차가 증가함에 따라 촬영 거리 감소에 따른 시각 피로 증가 가 더 분명하게 나타난다. 따라서 촬영 거리 변인과 수렴 조건 변인은 하나의 파라미터로 설명하는 것이 더 적절할 것으로 판단하였다. 따라서 회귀 분석에서는 촬영 거리 조건과 수렴 조건 변인의 두 변인을 바탕으로 거리 차이 변인을 계산하고 이 변인을 파라미터로 사용하였다 (표 3). 특히 이 두 변인의 조합이 화면 시차에 미치는 영향은 미터 단위의 역수인 디옵 터 단위에 선형적으로 비례하기 때문에 두 변수의 조합을 아 래 수식 1 과 같은 방법으로 계산하였다.

표 3. 촬영 거리 및 수렴 조건에 따른 거리 차이 표 Table 3. Distance differences determined by shooting distance and vergence condition

\begin{tabular}{|c|c|c|c|}
\hline \multirow{2}{*}{$\begin{array}{c}\text { Vergence } \\
\text { condition }\end{array}$} & \multicolumn{3}{|c|}{ Shooting distance $(\mathrm{m})$} \\
\cline { 2 - 4 } & 1 & 2 & 4 \\
\hline $\begin{array}{c}\text { Crossed } \\
\text { disparity }\end{array}$ & 0.6 & 0.3 & 0.15 \\
\hline No disparity & 0 & 0 & 0 \\
\hline $\begin{array}{c}\text { Uncrossed } \\
\text { disparity }\end{array}$ & 0.4 & 0.2 & 0.1 \\
\hline
\end{tabular}

$$
D_{d}=a b s\left(\frac{1}{D_{v}}-\frac{1}{D_{s}}\right),
$$


수식에서 거리 차이 $D_{d}$ 는 디옵터 단위로 변화시킨 수렴 거리인 $D_{v}$ 에서 촬영 거리인 $D_{s}$ 를 뺀 값에 절대 값을 취한 것이다. 앞서 언급한 바와 같이 이 값은 두 독립변인을 따로 사용하는 것에 비하여 좀 더 직접적으로 화면 시차에 연관 되는 값이며, 분석에서 사용한 결과 더 높은 설명력을 보였 다.

실험 결과를 기술하는 모형은 회전 오차와 거리 차이 값 을 사용하여 모형화 하였다. 회전 오차와 화면 시차가 시각 피로에 미치는 영향이 비선형적일 가능성이 존재하지만 자 료 양이 적고 모형의 단순성을 유지하기 위하여 선형 중다 회귀 모형을 사용하였다. 식은 수식 2에, 계수와 그 통계치 는 표 4에 제시되어 있다. 모형의 설명력 R2는 0.41 로 나타 났다.

$$
\hat{y}=b_{0}+b_{1} x_{1}+b_{2} x_{2}+b_{3} x_{1} x_{2}
$$

표 4.입체 시각 피로 예측 모형 계수

Table 4. Coefficients of 3D visual fatigue estimation model

\begin{tabular}{|c|c|c|c|c|}
\hline $\begin{array}{c}\text { Variable } \\
\text { name }\end{array}$ & Corresponding variable & Coefficient & $\mathrm{p}$ & Sig. \\
\hline$b_{0}$ & Intercept & 2.46 &. &. \\
\hline$b_{1}$ & $x_{1}$, roll misalignment & .59 & .000 & $<.001^{* * *}$ \\
\hline$b_{2}$ & $x_{2}$, distance difference & 3.72 & .000 & $<.001^{* * *}$ \\
\hline$b_{3}$ & $\begin{array}{c}x_{1} x_{2}, \text { roll misalignment } \\
\times \text { distance difference }\end{array}$ & -.86 & .000 & $<.001^{* * *}$ \\
\hline
\end{tabular}

그림 5에 실측치와 작성한 모형의 예측치를 제시하였다. 관측치는 속이 빈 원으로, 모형 예측치는 직선으로 표시하 였다. 또한 입체 시각 피로가 미약하다는 기준이 될 수 있는 3점을 점선으로 표시하였다. 이 모형의 예측치는 촬영 거리 및 수렴 조건이 입체 시각 피로에 미치는 영향 뿐 아니라 회전 오차가 화면 시차에 의하여 받는 영향 역시 잘 기술하 고 있다. 즉 모형은 화면 촬영 거리 및 수렴 조건에 의하여 변화하는 화면 시차의 크기를 잘 반영하고 있으며, 또한 화 면 시차가 작거나 없는 조건에서 회전 오차가 입체 시각 피로에 미치는 효과가 더 크게 나타나는 것 역시 잘 반영하 고 있다. 그리고 참가자가 입체 시각 피로가 미약하다고 응 답한 조건이 잘 반영되어 있어 카메라 파라미터 변화에 의
한 입체 시각 피로 하한선이 어떻게 되는지 잘 보여주고 있다.

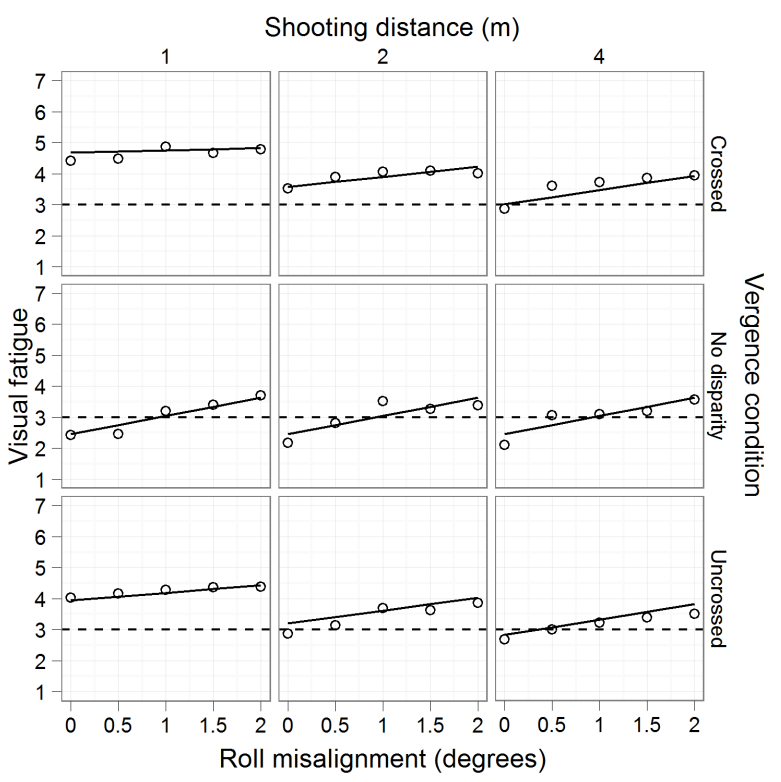

그림 5. 입체 시각 피로 측정치 및 모델 추정

Fig. 5. Observed $3 \mathrm{D}$ visual fatigue and estimated $3 \mathrm{D}$ visual fatigue by model

\section{III. 결론 및 논의}

본 연구는 입체 카메라를 사용하여 영상을 촬영할 때 광 축 오정렬에 의한 좌우 영상 차이가 시각 피로에 미치는 영향을 확인하고 그 결과를 모형화하기 위하여 수행되었다. 본 연구에서 관심을 가진 요인은 세 가지로, 광축 오정렬 요인 중 하나인 회전 오차와 화면 시차와 연관된 촬영 거리 및 수렴 거리 요인이다.

실험 결과 모든 독립변인이 입체 시각 피로에 영향을 미 쳤다. 회전 오차 증가에 따라 시각 피로가 증가하였고, 촬영 거리 감소에 따라 시각 피로가 증가하였으며, 수렴 거리와 촬영 거리 사이의 거리 차이가 증가할수록 시각 피로가 증 가하였다. 그러나 이런 효과는 단순하게 독립적으로 나타 나지 않았는데, 이는 상호작용 결과 분석에서 드러났다. 수 렴 거리와 촬영 거리의 2 원 상호작용에서 두 변인의 효과가 잠재적으로 수렴 조건에 의하여 나타남을 확인할 수 있었 
(Hyung-Chul O. Li et al. : The Effects of Roll Misalignment Errors, Shooting Distance, and Vergence Condition of 3D Camera on 3D Visual Fatigue)

다. 이는 입체 시각 피로는 화면 시차에 의한 수렴 조절 불 일치에 의하여 유발된다는 앞선 입체 시각 피로 연구 결과 와 일치한다 ${ }^{[2]}$. 그러나 회전 오차의 효과는 수렴 조건과 무 관하게 나타나는데, 촬영 거리 조건과 다르게 통상적으로 는 입체 시각 피로가 존재하지 않는 화면 시차가 없는 조건 에서도 입체 시각 피로를 유발시킨다. 이는 입체 영상 촬영 시 회전 오차가 반드시 해결되어야 할 문제임을 시사한다. 앞서 언급한 바와 같이 참가자들이 시각피로가 미약하다 고 응답한 경우 (즉 피로 점수 3점 이하)를 기준으로 생각하 면, 회전 오차의 효과는 이미 존재하는 화면 시차의 크기에 따라서 다르게 작동한다고 생각할 수 있다. 즉 이미 큰 화면 시차를 가지고 있으며 그 때문에 높은 입체 시각 피로를 보이는 촬영거리 $1 \mathrm{~m}$ 조건 교차 / 비교차 조건의 경우, 회전 오차 증가에 따른 입체 시각 피로 증가가 두드러지게 나타 나지 않는다. 특히 더 높은 화면 시차를 가지는 교차 시차 조건에서는 회전 오차의 효과가 거의 나타나지 않는다. 이 는 회전 오차의 효과가 결국 화면 시차를 발생시키기 때문 에 나타난 것임을 암시하는데, 이는 회전 오차가 특히 화면 시차가 없는 조건에서 시각피로에 큰 영향을 미치며, 화면 시차의 크기가 작아짐에 따라 (즉 촬영거리가 멀어짐에 따 라서) 화면 시차가 주어지는 조건에서도 점점 더 큰 효과를 보이는 것에서 확인할 수 있다. 즉, 회전 오차는 작은 양의 화면 시차를 더해주는 역할을 하며 이는 입체 시각 피로에 직접 영향을 미친다.

이런 결과는 실제 대상을 촬영하여 입체 영상을 구성해 야 하는 경우 유용하게 쓸 수 있을 것이다. 특히 회전 오차 의 효과는 일반적으로 입체 시각 피로를 유발시키지 않는 것으로 알려진 화면 시차가 없거나 적은 조건에서 더 크게 드러나기 때문에 입체 시각 피로를 낮게 유지해야 하는 영 상인 경우 더 주의하여야 할 것이다. 본 연구의 측정 결과에 따르면 화면 시차가 없거나 상대적으로 낮은 경우, 회전 오 차에 의한 추가적인 입체 시각 피로 증가를 막으려면 회전 오차를 최소한 $0.5^{\circ}$ 이하로 유지시켜야 한다.

그러나 본 연구에서 측정한 결과와 시각 피로 모델만으 로 모든 오정렬 요인에 대한 설명을 할 수 있는 것은 아니
다. 왜냐하면 카메라 오정렬에 의한 양안 영상 차이는 상/ 하, 좌/우, 앞/뒤 등 매우 다양한 측면에서 발생할 수 있기 때문이다. 또한 이런 카메라 오정렬이 미치는 영향이 서로 상호작용 하는지 밝혀내려면 하나의 카메라 오정렬 요인만 사용된 본 연구의 결과를 확장한 추가적인 연구가 필요하 다. 또한 이런 연구를 통하여 카메라 오정렬에 의하여 나타 난 시각 피로 증가가 어떤 특성을 가지고 있는지 검증해볼 수 있을 것이다. 본 연구에서는 회전 오차의 증가가 일종의 추가적인 화면 시차처럼 시각 피로에 영향을 미쳤다. 그러 나 이 효과가 어떻게 구성된 것인지 그 원인을 밝히려면 이 연구의 결과를 확장한 추가적인 연구가 필요할 것이다.

\section{참 고 문 헌}

[1] Marr, D. Vision: A Computational Approach, Freeman \& Co., San Francisco, 1982

[2] Hoffman, D. M., Girshick, A. R., Akeley, K., and Banks, M. S., Vergence-accommodation conflicts hinder visual performance and cause visual fatigue, Journal of Vision, 8(3), 33, pp.1-30, 2008

[3] Julesz, B., Foundations of cyclopean perception, University of Chicago Press, Chicago, 1971

[4] Palmer, S. E., Vision science: Photons to phenomenology (Vol. 1), MIT press, Cambridge, 1999

[5] Shibata, T., Kim, J., Hoffman, D. M., \& Banks, M. S., The zone of comfort: Predicting visual discomfort with stereo displays. Journal of vision, 11(8), pp.1-29, 2011, http://www.journalofvision.org/content/11/8/11, doi:10.1167/11.8.11

[6] Li. H. C. O., Human Factor Research on the Measurement of Subjective Three Dimensional Fatigue, Journal of Broadcast Engineering of Korea, 15(5), pp.607-616, 2010

[7] Li. H. C. O., Measurement of the Perceptual Distortion of 3D Depth/Shape in Realistic Broadcasting. Journal of Broadcast Engineering of Korea, 14(2), pp.210-218, 2009

[8] Woods A, Docherty. T, and Koch. R, Image Distortions in Stereoscopic Video Systems, Proc. SPIE 1915, pp.36-49. 1993.

[9] F.L. Kooi and A. Toet, "Visual comfort of binocular and 3D displays," Displays, 25(2), pp. 99-108, 2004.

[10] Brainard, D. H., The Psychophysics Toolbox, Spatial Vision, 10, 433-436, 1997

[11] Pelli, D. G., The VideoToolbox software for visual psychophysics: Transforming numbers into movies, Spatial Vision, 10, 437-442, 1997

[12] Kleiner, M., Brainard, D., Pelli, D., What's new in Psychtoolbx-3?, PerceptionECVP Abstract Supplement, 2007 


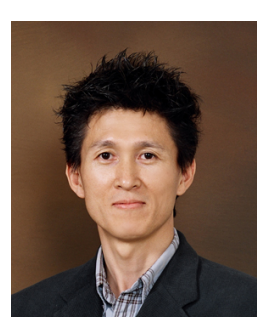

\section{이 형 철}

- 1987년 : 연세대학교 심리학과 학사

- 1989년 : 연세대학교 심리학과 석사

- 1996년 : 미국 University of Wisconsin, Madison, 심리학과 박사

- 1999년 현재 : 광운대학교 산업심리학과 교수

- 2010년 2011년 : TTA, 3DTV PG, 품질안전규격 WG 의장

- 2010년 2011년 : $3 D$ 시청 안전성 협의회 의장

- 주관심분야 : 3D 휴먼팩터, 시지각, Brain-Computer Interface

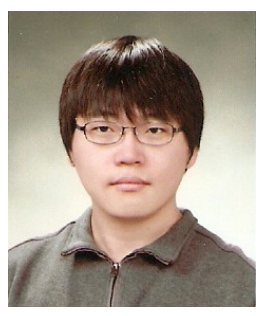

\section{박 종 진}

- 2009년 : 광운대학교 산업심리학과 학사

- 2011년 : 광운대학교 산업심리학과 석사

- 2011년 현재 : 광운대학교 산업심리학과 박사과정

- 주관심분야 : $3 \mathrm{D}$ 휴먼팩터, 시지각

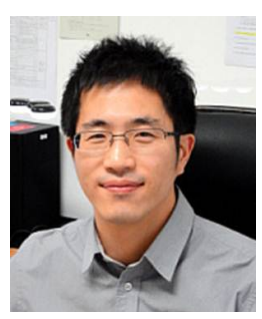

\section{김 신 우}

- 2003년 : 연세대학교 심리학과 학사

- 2007년 : New York University 심리학과 석사

- 2010년 : New York University 심리학과 박사

- 2010년 현재 : 광운대학교 산업심리학과 조교수

- 2010년 현재 : 감성과학회 편집위원

- 주관심분야 : 시선추적, 범주화, 인과관계, 개념학습, 추론, 사용성 